\title{
A Musical Club
}

Author(s): C. L. Williams

Source: The Musical Times and Singing Class Circular, Vol. 23, No. 469 (Mar. 1, 1882), p. 159

Published by: Musical Times Publications Ltd.

Stable URL: http://www.jstor.org/stable/3358546

Accessed: 06-06-2016 03:17 UTC

Your use of the JSTOR archive indicates your acceptance of the Terms \& Conditions of Use, available at

http://about.jstor.org/terms

JSTOR is a not-for-profit service that helps scholars, researchers, and students discover, use, and build upon a wide range of content in a trusted digital archive. We use information technology and tools to increase productivity and facilitate new forms of scholarship. For more information about JSTOR, please contact support@jstor.org.

Musical Times Publications Ltd. is collaborating with JSTOR to digitize, preserve and extend access to The Musical Times and Singing Class Circular 


\section{CORRESPONDENCE.}

\section{LOCKE'S MUSIC TO MACBETH.}

TO THE EDITOR OF "THE MUSICAL TIMES."

Sir,--In the review of the biography of Purcell by $\mathrm{Mr}$. Cummings in the current number of THE Musical TIMES, it is stated that "amongst the many errors corrected by Mr. Cummings is that which connects the name of Matthew Locke with the Music to "Macbeth." It appears Mr. Cummings possesses a manuscript score of the music in Purcell's "youthful hand." Now the music was produced in 1674 , when Purcell was but a boy in his sixteenth year; and surely the fact that a copy of the score exists in his handwriting cannot be viewed as an argument that he was the composer. The internal evidence is alluded to; but to myself that would render it still more improbable that Purcell could have written it. The melodies are throughout too smooth and polished, and the choruses too matured in style, to have been the work of the boy Purcell.

The Music to "Macbeth" was doubtless not printed till long after its first production; and when, later on, Purcell's genius shone forth in full splendour, nothing would be more natural than that any composition of great merit, whose authorship was not stated, should be attributed to him.

I have in my possession three different biographical notices of Matthew Lock (sic) written some forty or fifty years ago, each ascribing the music in question to Lock; one notices the fact that several attempts had been made to deprive him of the authorship, but "without the shadow of an argument" to support them.

It would appear that Lock's contemporaries generally attributed the music to him; and what to me is, beyond all, conclusive is that Downes, who was connected with the Duke's Theatre at the time the music was produced there, speaks of Lock as the composer.

Over two centuries have now elapsed since this noble music was first given to the world, and I submit it is too late in the day to prove that the composer of the Music to "Macbeth" was any other than Matthew Lock.

February I7, I882.

Justitia.

\section{SCOTT AND PURCELL.}

TO THE EDITOR OF "THE MUSICAL TIMES."

SIR,-The following quotation, from the "Life of Purcell," by Cummings, briefly but clearly summarises the truth respecting the dedication of the "Orpheus Britannicus" and the erection of Purcell's monument :-

This memorial was erected by the Lady Elizabeth Howard, whom Hawkins and others have supposed to be the wife of Dryden, and a pupil of Purcell. Hawkins also inferred that it was Dryden who wrote the inscription for the memorial, and further, that the dedication of the "Orpheus Britannicus" to Lady Elizabeth Howard was intended for Dryden's wife. All these surmises are wrong. Dryden married Lady Elizabeth Howard, the eldest daughter of the Earl of Berkshire,
in 1665 , when Purcell was seven years old. Of course, after the marin 1665 , when Purcell was seven years old. Of course, after the marriage the wife ceased to be Lady Elizabeth Hovvard; moreover, her husband's (Dryden) means would scarcely have permitted the serious cost of Purcell's memorial tablet. This was in reality erected by the wife of Sir Robert Howard, the dramatist, who had been associated with Purcell in theatrical composition; and the lady had been a pupi inscription.

Hawkins supposed that Dryden wrote "Alexander's Feast" for Purcell, and penned some curious observations concerning Purcell's inability or unwillingness to set the ode to music. This myth is also refuted by Mr. Cummings, who quotes proofs from Scott's "Life of Dryden." Yours, \&c. HISTORIAN.

\section{ILI-TIMED APPLAUSE.}

TO THE EDITOR OF "THE MUSICAL TIMES."

SIR,-I am an amateur horn-player from the country, and on Wednesday last I went to the Albert Hall to hear the "Hymn of Praise" and "Stabat Mater."

It is not overstating my case when I say that my chief attraction was the small opening by the horns of the No. 3 in the "Stabat Mater," for, having played in it more than once in the country, I was most anxious to hear'it; but a portion of the audience were so much pleased with the gentleman who took the voice part in No 2 that they continued their applause well into No. 3. I was, as you may imagine, bitterly disappointed, for not a note of my beloved horns did I hear. I comforted myself, however, with the thought that these bars were repeated at the end of the number; but the ladies had not closed their mouths when the noise began again, and I was altogether sold.

Now, sir, cannot something be done to abate this nuisance? Surely the promoters of concerts have the matter in their own hands; and if on the programmes the public were requested not to cheer till the music ceased I believe they would abstain from doing so. If this failed it would be only a just retaliation for the lovers of instrumentation to applaud their favourite bits in the middle of the solos for voices.-I am, \&c.,

February II, I882.

C. A. W. T.

\section{MALE-VOICE CHOIRS.}

TO THE EDITOR OF "THE MUSICAL TIMES."

SIR,-I have read with very much interest the correspondence which has been going on in your columns with reference to the above, and have been not a little surprised to see that no one has thought it worth while to bring before the notice of your readers a Male-Voice Society so well known in the West of England as the Bristol Orpheus. Established, I believe, nearly forty years, this Society has gained the reputation of being one of the best known. It consists of about sixty members (with altos for the top line), and is fortunate in having for its conductor Mr. George Riseley, organist of Bristol Cathedral, whose ability has brought the Society no little fame. Their last "Ladies' Night " took place on February 16 , and brought together one of the largest and most fashionable audiences ever seen in the Colston Hall. Glees by Cooke, Wesley, Goss, and other eminent composers were rendered in a manner as near perfection as possible, and the local press characterised the performance as unique and were loud in praise.

If the Bristol Orpheus were to give a concert in London, I feel certain that the performance would go far to prove that there is a Society capable of rendering some of the finest male-voice glees in a most efficient manner. Yours truly,

\section{BRISTOLIAN.}

\section{RULE FOR FINDING WHAT AN INTERVAL} WILL BECOME BY INVERSION.

TO THE EDITOR OF "THE MUSICAL TIMES."

Sir,-In The Musical Times for November, I88I, the appreciative reviewer of Dr. Bridge's "Double Counterpoint and Canon" commends the system of finding what an interval will become by inversion, as given by the learned Doctor, and says : "We do not remember to have seen such rule given in any work on Double Counterpoint up to the present time."

The rule referred to was first given, I believe, by Johann Albrecht Schulz, in the article "Versetzung" in Sulzer's "Theorie der schönen Künste," published at Berlin in 1774

Albany, New York, Yours very truly,

January I8, I 882 .

JoHN KANTz.

\section{A MUSICAL CLUB.}

TO THE EDITOR OF "THE MUSICAL TIMES."

SIR,-I often wonder if it would be possible to form a Musical Club in London: it would be a great boon to organists and musical men living in the country. To take my own experience (which possibly is the same as many other organists), I generally manage to get a fortnight in London in May, and many times have felt the want of a place to go to where I could meet other musical men and hear what is going on in the musical world generally. If some leading London organists, publishers, or institutions would take up this idea, I feel sure they would meet with the support of many of their country brethren.

Llandaff, February 20 Faithfully yours 